Chirurgia (2021) 116: 748-755

No. 6, November - December

Copyright@ Celsius

http://dx.doi.org/10.21614/chirurgia.116.6.748

\title{
Clinical-Pathological Correlations in the Acute Surgical Abdomen in the Pre and Post-Pandemic Period Covid-19
}

\author{
Cosmin Nicolescu ${ }^{1,2}$, Vlad Olimpiu Butiurca ${ }^{1,2}$, Cătălin Cosma ${ }^{1,2 *}$, Mihai Bălan², Ioana Iulia Cojocaru', \\ Hunor Kovacs ${ }^{2}$, Mircea Gherghinescu ${ }^{1,2}$, Cristian Russu ${ }^{1,2}$, Dan Popa ${ }^{1,2}$, Andrei Modiga ${ }^{1,2}$,Tudor Adrian', \\ Bogdan Suciu', ${ }^{1,2}$ Călin Molnar ${ }^{1,2}$
}

${ }^{1}$ George Emil Palade University of Medicine, Pharmacy, Science and Technology of Targu Mures, Romania ${ }^{2}$ General Surgery I, Emergency County Hospital, Targu Mures, Romania

*Corresponding author:

Cătălin Cosma, MD

General Surgery I

Emergency County Hospital

Targu Mures, Romania

E-mail: cosma.catalin.dumitru@gmail.com

\section{Rezumat \\ Corelații clinico-patologice în abdomenul acut chirurgical în perioada pre și post-pandemică Covid-19}

Introducere: În cazul pacienților internați cu abdomen acut în urgențe, patologia pulmonară interstițială (infecții cu Covid-19) reprezintă un risc operator semnificativ pentru pacienți. Rata complicațiilor postoperatorii este mare, cu morbiditate şi mortalitate crescută, o adevărată provocare pentru personalul medical şi echipele unității de chirurgie/terapie intensivă. În situații de urgență, pacienții au fost examinați cu parametri clinici şi paraclinici țintiți care pot asigura un diagnostic rapid pentru a optimiza un tratament medical şi chirurgical rapid.

Metode: Am realizat un studiu comparativ retrospectiv care a inclus pacienți diagnosticați cu abdomen acut chirurgical în Clinica Chirurgie I, Spitalul Județean de Urgență Tg. Mureş. Pacienții au fost examinați clinic şi paraclinic la secția de urgențe UPUSMURD. Am inclus pacienții internați în cei doi ani (2019 şi 2020) cu împărțirea acestora în două grupuri.

Rezultate: Numărul total de pacienți internați în secția de urgență UPU- Smurd, Clinica Chirurgie I pe parcursul celor doi ani a fost de 1033. S-a înregistrat o reducere semnificativă a totalului cazurilor diagnosticate cu abdomen acut chirurgical în perioada de pandemie $(p=0,033)$. Timpul mediu de la internarea la procedura chirurgicală a fost semnificativ mai mare în perioada de pandemie $380 \pm 2 \min$ în comparație cu $222 \pm 3 \min (\mathrm{p}=0,001)$ şi, de asemenea, cu un timp operator mediu crescut $223 \pm 3$ min față de $145 \pm 2$ min. 
$(p=0,002)$. Perioada de spitalizare a fost mai mare în pandemie $10 \pm 1$ zile $(p=0,031)$, fără diferențe semnificative între grupuri în ceea ce priveşte internarea la Terapie Intensivă $(p=0,122)$. Mortalitatea totală s-a dublat procentual, cu 31 de cazuri (19\%) în pandemie şi 28 cazuri (9\%) în non-pandemie. $(\mathrm{p}=0,001)$.

Concluzie: Pandemia COVID-19 a jucat un rol esențial în tratarea cazurilor de abdomen acut chirurgical. Rata mare de solicitare a serviciilor de urgență a întârziat diagnosticul şi tratamentul cazurilor chirurgicale severe. Deoarece amploarea acestei pandemii este fără precedent, protocoalele standard cu modificări minore nu oferă rezultate adecvate.

Cuvinte cheie: abdomen acut chirurgical, COVID-19, chirurgie de urgență, prepandemie, pandemie

\begin{abstract}
Background:In the case of patients admitted with acute abdomen at the emergency department, interstitial pulmonary pathology (Covid-19 infections) represents a significant operative risk for the patients. The rate of postoperative complications is high with increased morbidity and mortality, a real challenge for the medical staff and surgical/intensive care unit teams. In emergency settings, patients were examined with targeted clinical and paraclinical parameters that assure a fast diagnosis to optimize a rapid medical and surgical treatment.

Methods: We conducted a retrospective comparative study that included patients enrolled and diagnosed with an acute surgical abdomen in Surgical Clinic 1-Tg. Mures Emergency County Hospital. Patients were examined and analyzed at the emergency department UPU-SMURD. We included patients admitted over the two years (2019 and 2020) and divided them into two groups. Results: The total number of patients admitted in the UPU-Smurd emergency department Surgical Clinic I over the two years was 1033. There was a significant reduction in total cases diagnosed with the acute surgical abdomen in the pandemic period $(\mathrm{p}=0.033)$. The average time from the admission to the surgical procedure was significantly higher in the pandemic period $380 \pm 2 \mathrm{~min}$ in comparison with $222 \pm 3 \mathrm{~min}(\mathrm{p}=0.001)$ and also with an increased average operative time $223 \pm 3 \mathrm{~min}$ versus $145 \pm 2 \mathrm{~min}(\mathrm{p}=0.002)$. Average hospitalization time was higher in the pandemic period $10 \pm 1(\mathrm{p}=0.031)$ with no significant difference between the groups regarding Intensive Care Unit (ICU) admission $(\mathrm{p}=0.122)$. Overall mortality has more than doubled, with 31 cases $(19 \%)$ in the pandemic and $28(9 \%)$ in the non-pandemic. $(\mathrm{p}=0.001)$.

Conclusions: The COVID-19 pandemic has played an essential role in treating acute surgical abdomen cases. The high solicitation rate of the emergency department delayed the diagnosis and treatment of severe surgical cases. As the scale of this pandemic is unprecedented, standard protocols with minor changes do not provide adequate results
\end{abstract}

Key words: acute surgical abdomen, COVID-19, emergency surgery, prepandemic, pandemic

\section{Introduction}

In the case of patients admitted with acute abdomen in the emergency department, interstitial pulmonary pathology (Covid-19 infections) represents a significant operative risk for the patients $(1,2,3)$. The rate of postoperative complications is high with increased morbidity and mortality, a challenge for the medical staff and surgical/intensive care unit teams (5-7). In emergency settings, patients are examined with targeted clinical and paraclinical parameters that assure a fast diagnosis to optimize a rapid medical and surgical treatment (4). These parameters are vital in treating acute abdomen cases, 
especially when it involves traumatic pathology or patients with advanced diseases with unstable conditions (5-7). Pandemic conditions with increased emergency cases regarding respiratory pathology can disrupt or delay the treatment of surgical patients that require immediate diagnosis and treatment. The study aims to analyze the difference between the surgical management of patients during the pandemic and non-pandemic period and to determine the challenges and management of acute abdomen cases in the pandemic scenario $(2,3)$.

\section{Material and Method}

We conducted a retrospective comparative study that included patients enrolled and diagnosed with an acute surgical abdomen in Surgical Clinic 1 - Tg. Mures Emergency County Hospital. Patients were examined and diagnosed at the emergency department UPUSMURD. We included patients admitted over the two years (2019 and 2020) and divided them into the pre-pandemic control group from 2019 and the pandemic group from 2020. We excluded patients with abdominal colics, thoracic pathology, and other emergency surgical procedures not diagnosed as an acute surgical abdomen. We divided the patients after postoperative diagnosis following the acute surgical abdomen intervention as follows: acute cholecystitis, acute appendicitis, incarcerated hernia, perforated ulcer, intestinal occlusion (neoplasms or internal hernia/ adherence), acute mesenteric ischemia, blunt abdominal trauma, and penetrating abdominal trauma. The evaluation of the cases was conducted by analyzing the physical, imaging, and laboratory examination data, the operative protocols, and the postoperative results collected from the written and electronic database of the $1^{\text {st }}$ Department of General Surgery and the Department of Emergency (UPU-SMURD) County Hospital of Targu Mures. The study was conducted following the Declaration of Helsinki (1964) and approved by the Emergency County Hospital of Targu Mures Ethics Committee. All the patients included in this study underwritten informed consent at admission. They met all conditions of EU professional ethics. Data collection has been processed in Microsoft Excel, and statistical analysis was conducted using Graph Pad Prism 6. We used statistical methods such as descriptive and analyticinferential methods. We used at Student test to evaluate the differences between the means of continuous variables in two groups and the ANOVA test to assess the differences between the means of continuous variables in four groups (expressed by mean \pm SD). We applied a $\chi^{2}$ test for categorical variables (defined by $\mathrm{nr}$ $(\%)$. Comparison of differences between nonparametric variables (represented by median, range) was analyzed with the Mann-Whitney $\mathrm{U}$ test. All the tests we have performed to materiality $\mathrm{p}=0.05$ and statistical significance were considered in case of $p$ values less than the threshold value of significance

\section{Results}

The total number of patients admitted in the UPU-Smurd emergency department - Surgical Clinic I over the two years was 1033. A total number of $(n=405)$ patients were excluded based on the diagnosis criteria (acute nonsurgical abdomen) and $(n=105)$ were excluded as pure thoracic trauma (blunt or penetrating) and other pathological cases. The prepandemic lot included $(\mathrm{n}=312)$ patients and the pandemic lot ( $\mathrm{n}=166$ patients) (Fig. 1).

The average age was $59 \pm 1.2$ years for the pre-pandemic period and $62 \pm 1.5$ for the pandemic. In the pandemic lot, we observed a male dominance of $56 \%$ in comparison with the non-pandemic lot of $(48 \%) \quad(p=0.648)$. There was a significant reduction in total cases diagnosed with acute surgical abdomen in the pandemic period $(\mathrm{p}=0.033)$ (Table 1 ).

The average time from the admission to the surgical procedure was significantly higher in the pandemic period $380 \pm 2$ min in comparison with $222 \pm 3 \mathrm{~min}(\mathrm{p}=0.001)$ and also with an increased average operative time $223 \pm 3 \mathrm{~min}$ versus $145 \pm 2 \mathrm{~min}(\mathrm{p}=0.002)$. Average hospitalization time was higher in the pandemic period 


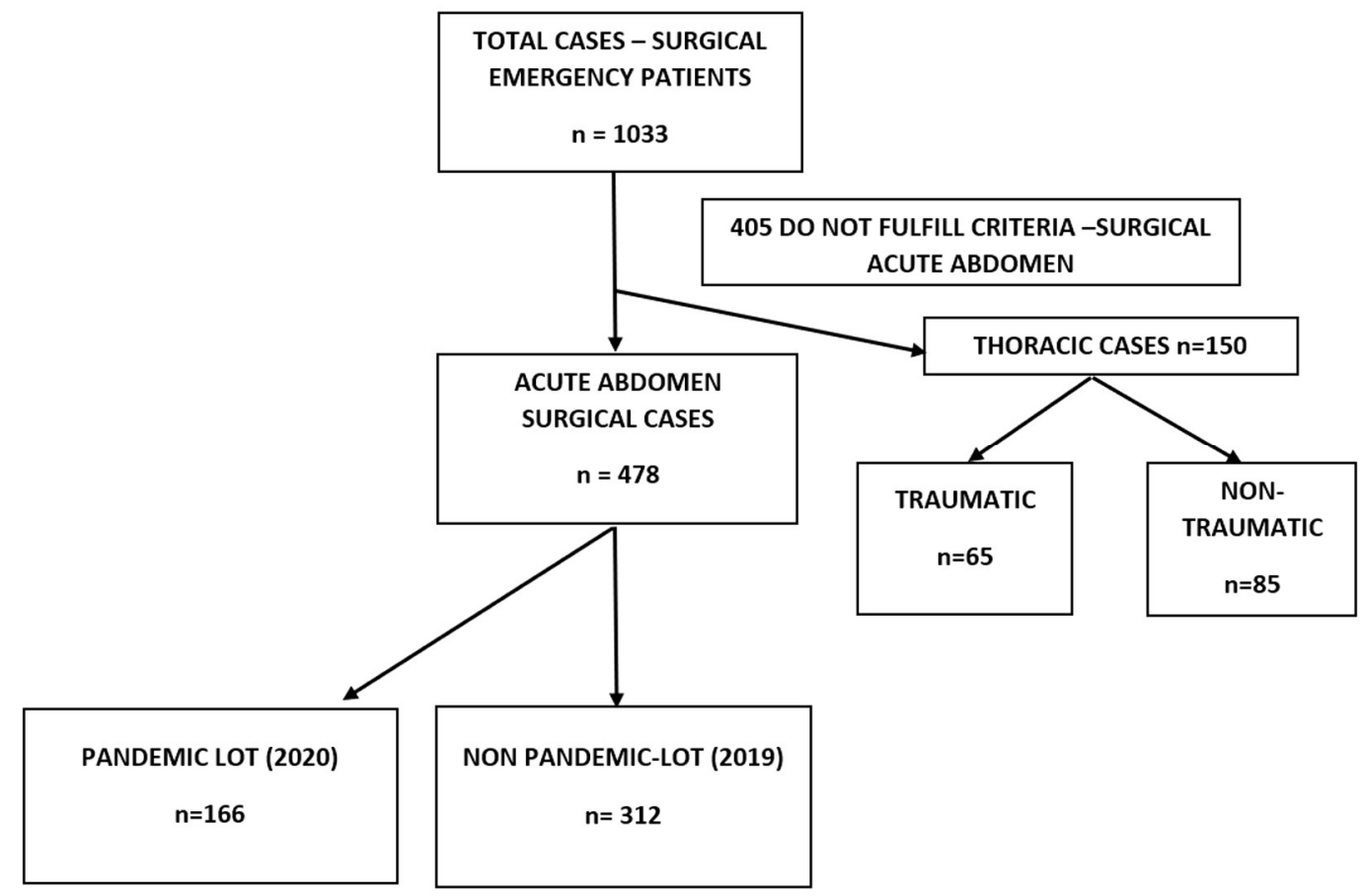

Figure 1. Exclusion of non-acute surgical abdomen cases

Table 1. Demografic and discriptive data

\begin{tabular}{lccc}
\hline Criteria & Non-Pandemic & Pandemic & p-value \\
\hline Emergency cases & 597 & 436 & $0.003^{*}$ \\
\hline Acute abdomen cases + thoracic & 390 & 238 & $0.001^{*}$ \\
\hline Acute abdomen cases & 312 & 166 & $0.033^{*}$ \\
\hline Median age & $59 \pm 1.2$ & $62 \pm 1.5$ & $0.544^{*}$ \\
\hline Gender M & $187(48 \%)$ & $133(56 \%)$ & $0.648^{*}$ \\
\hline \multicolumn{1}{c}{ F } & $203(52 \%)$ & $105(44 \%)$ & $0.444^{*}$ \\
\hline
\end{tabular}

* Mann-Whitney U test

$10 \pm 1 \quad(p=0.031)$ with no significant difference between the groups regarding Intensive Care Unit (ICU) admission $(p=0.122)$. Overall mortality doubled with 31 cases $(19 \%)$ in the pandemic and 28 (9\%) in the non-pandemic. $(\mathrm{p}=0.001)$ (Table 2, Fig. 2).
Regarding postoperative surgical diagnosis, we observed the following: in patients diagnosed with acute cholecystitis, the number of cases was significantly higher $(n=60)$ in the nonpandemic group $(p=0.001)$, and the surgical procedure time on average was higher in the

Table 2. Admission and medical-surgical procedures data

\begin{tabular}{lccc}
\hline Interval-Procedures & Non-Pandemic & Pandemic & p-value \\
\hline Admission - surgical procedure & $222 \pm 3 \mathrm{~min}$ & $380 \pm 2 \mathrm{~min}$ & $0.001^{\star}$ \\
\hline Surgical procedure time (mean) & $145 \pm 2 \mathrm{~min}$ & $223 \pm 3 \mathrm{~min}$ & $0.002^{\star}$ \\
\hline General days of admission & $7 \pm 2$ & $10 \pm 1$ & $0.031^{\star}$ \\
\hline Intensive care (ICU) admission & $6 \pm 0.5$ & $10 \pm 0.5$ & $0.122^{\star}$ \\
\hline Mortality & $28 / 312(9 \%)$ & $31 / 166(19 \%)$ & $0.001^{\star}$ \\
\hline
\end{tabular}

(min) (mean \pm SD)

* Mann-Whitney U test 
Figure 2. Medico-surgical treatments

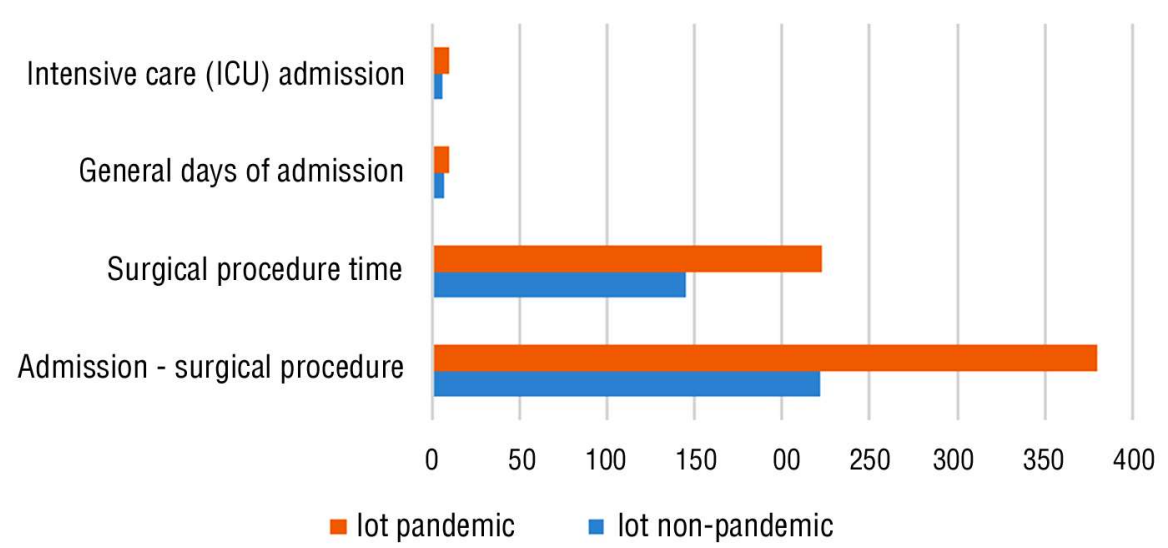

pandemic lot $266 \pm 3 \mathrm{~min}(\mathrm{p}=0.002)$; for acute appendicitis, the number of cases was significantly reduced $(n=22)$ in the pandemic lot $(p=0.001)$ with increased average surgical intervention time $198 \pm 2 \mathrm{~min}(\mathrm{p}=0.004)$; There was a reduction of incarcerated hernias in the pandemic lot $(\mathrm{n}=7)(\mathrm{p}=0.001)$ with no significant difference in surgical intervention time $(p=0.543)$; Cases with intestinal occlusion were lower in the pandemic period $(n=67)$ in comparison with $(n=118)(p=0.001)$. There were no statistically significant results regarding acute mesenteric ischemia and perforated ulcer disease between the lots. In the traumatic acute surgical abdomen, we observed a substantial difference in the blunt trauma category $(n=20)$ versus $(n=40)(p=0.001)$ with decreased operation time in the pandemic lot $88 \pm 2 \mathrm{~min}$ $(\mathrm{p}=0.001)$ (Table 3, Fig. 3).

We analyzed the specific paraclinical parameters. Hepatic status markers: direct bilirubin (DB), total bilirubin (TB), and transaminase (GOT and GPT). We collected data at admission and discharge. We observed a difference regarding the TB that was higher in the pandemic lot at admission $(1.9 \mathrm{mg} / \mathrm{dl})$ $(p=0.033)$ and GOT $77.4 \mathrm{UI} / \mathrm{l}(\mathrm{p}=0.006)$. At discharge the statistically significant difference was with DB (0.7) $(\mathrm{p}=0.042)$ and GOT 69.5 UI/l $(\mathrm{p}=0.003)$ (Table 4$)$.

Table 3. Procedures based on postoperative diagnosis

\begin{tabular}{|c|c|c|c|}
\hline Diagnosis & Non-Pandemic & Pandemic & p-value \\
\hline Acute cholecystitis & $60 / 312$ & $26 / 166$ & $0.001^{*}$ \\
\hline Surgical intervention (min) (mean \pm SD) & $155 \pm 4 \min$ & $266 \pm 3 \mathrm{~min}$ & $0.002^{\star}$ \\
\hline Acute appendicitis & $40 / 312$ & $22 / 166$ & $0.001^{*}$ \\
\hline Surgical intervention (min) (mean \pm SD) & $122 \pm 3.2 \mathrm{~min}$ & $198 \pm 2 \min$ & $0.004 *$ \\
\hline Perforated ulcer & $12 / 312$ & $9 / 166$ & $0.784^{*}$ \\
\hline Surgical intervention (min) (mean \pm SD) & $147 \pm 2.3 \mathrm{~min}$ & $122 \pm 2 \min$ & $0.442^{\star}$ \\
\hline Acute mesenteric ischemia & $17 / 312$ & $12 / 166$ & $0.348^{*}$ \\
\hline Surgical intervention (min) (mean \pm SD) & $123 \pm 2 \min$ & $166 \pm 3 \mathrm{~min}$ & $0.234^{\star}$ \\
\hline Incarcerated hernia & $18 / 312$ & $7 / 166$ & $0.001^{\star}$ \\
\hline Surgical intervention (min) (mean \pm SD) & $180 \pm 3 \min$ & $210 \pm 4 \min$ & $0.564^{\star}$ \\
\hline Intestinal occlusion & $118 / 312$ & $76 / 166$ & $0.001^{*}$ \\
\hline Surgical intervention (min) (mean \pm SD) & $196 \pm 2.2 \mathrm{~min}$ & $240 \pm 2 \min$ & $0.010^{*}$ \\
\hline Blunt trauma & $40 / 312$ & $20 / 166$ & $0.001^{\star}$ \\
\hline Surgical intervention (min) (mean \pm SD) & $144 \pm 3.2 \mathrm{~min}$ & $88 \pm 2 \min$ & $0.001^{\star}$ \\
\hline Penetrating trauma & $7 / 312$ & $3 / 166$ & $0.311^{*}$ \\
\hline Surgical intervention (min) (mean \pm SD) & $177 \pm 3.1 \mathrm{~min}$ & $157 \pm 1 \mathrm{~min}$ & $0.511^{\star}$ \\
\hline
\end{tabular}

* Mann-Whitney U test 
Figure 3. Operative time - postoperative diagnosis

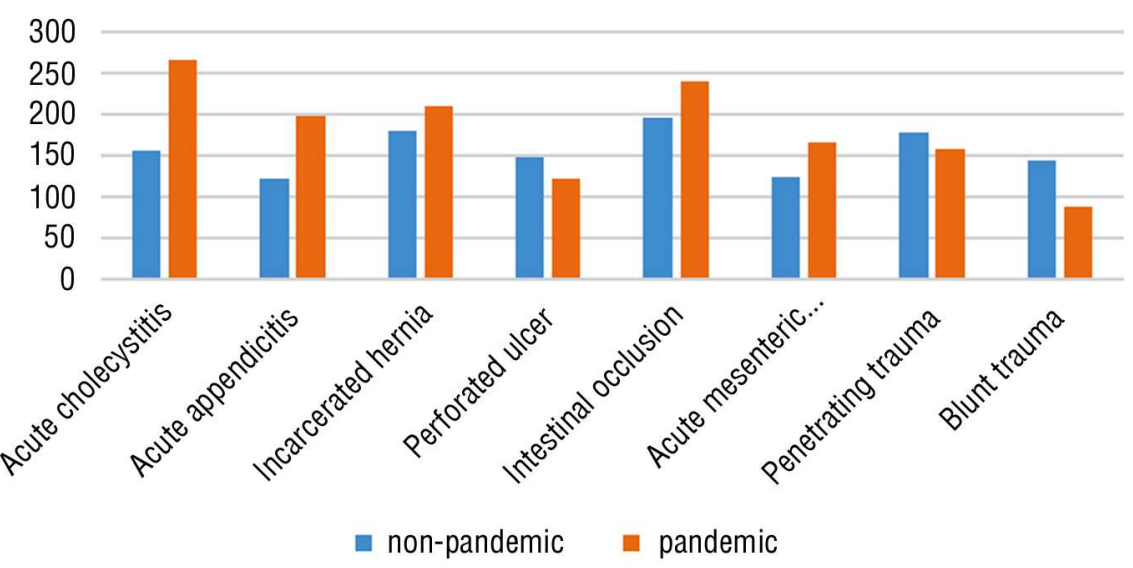

\section{Discussions}

The reorganization was imposed in the clinical and surgical departments at the start of 2020 due to the COVID19 pandemic. We carried out this reorganization to ensure the necessary resources to continue the surgical activity on the one hand and on the other hand to protect the medical staff, respectively, of the patients against the SARS-COV-2 infection. (8) From the beginning, we considered that the highest risk of infection of medical staff occurs at the time of intubation, detubation of the patient, or during surgery on the respiratory system. $(9,10)$ At the same time, surgery should be performed in full knowledge of the case, in the sense of knowing the patient's infectious status if the patient's general condition allows the postponement of the surgery for a period.
Also, maintaining the health of medical staff in surgical wards is particularly important in maintaining these services' functionality. Therefore, most patients undergoing surgery were considered positive for SARS-COV-2 infection in most surgical services until we obtained viral test results. (4) In this respect, the existence of operating rooms with negative pressure was of particular importance, knowing that in these situations, the risk of contamination of medical staff is lower even if the patient is infected. (11) Another crucial aspect during the COVID19 pandemic was the reorganization of patient flows in surgical services into COVID and non-COVID sections. Often, this fact has led to an increase in the waiting period in emergency services in clinical practice. Lack of addressability of patients in the emergency services was present probably

Table 4. Paraclinical parameters

\begin{tabular}{lccc}
\hline Paraclinical Test & Non-Pandemic & Pandemic & p value \\
\hline Admission & & & $0.003^{*}$ \\
\hline Direct Bilirubin (DB) & 0.7 & 0.9 & $0.001^{*}$ \\
\hline Total Bilirubin (TB) & 1.3 & 1.9 & $0.033^{\star}$ \\
\hline Transaminases -GOT & 57.8 & 77.4 & $0.544^{*}$ \\
\hline Transaminases -GPT & 65.3 & 69.5 & $0.648^{*}$ \\
\hline Discharge & & & $0.444^{*}$ \\
\hline Direct Bilirubin (DB) & 0.4 & 0.7 & $0.648^{*}$ \\
\hline Total Bilirubin (TB) & 1.1 & 1.2 & $0.444^{*}$ \\
\hline Transaminases -GOT & 53.8 & 69.5 & \\
\hline Transaminases -GPT & 63.5 & 66.8 & \\
\hline DB, TB - mg/dl & & & \\
GOT, GPT - Ul/l & & &
\end{tabular}


due to fear of contact with the virus in the hospital (12). In this respect, one of the main effects of these truths was that sometimes patients presented to the hospital in a much more severe clinical condition, which affected their prognosis (13). All of these issues have ultimately led to declining patients' confidence in the healthcare system during the COVID-19 pandemic (14). Given that most COVID-19 infected patients may be asymptomatic, especially in patients who require emergency surgical treatment (acute traumatic or nontraumatic surgical abdomen), it is often difficult to wait for the result of the PCR test. That is why most authors recommend performing chest CT scans in all patients, knowing that pulmonary opacity in "frosted glass" is the most accurate indirect sign on computer tomographic examination $(15,16)$. These recommendations were also followed by us in clinical practice, knowing that postoperative morbidity and mortality in COVID infected patients increases exponentially (17). Regarding the cases of polytraumatized patients hospitalized, we noticed a decrease in their number due to the social distance and limited mobility between different cities. Other studies published in the literature mentioned this fact (18). The decrease in the number of polytraumatized patients who presented to the emergency services also represented a positive fact, in the sense that the need for blood, respectively blood preparations in the medical services decreased, a fact also observed by us in our clinical practice (19). In our statistics, we did not observe statistically significant differences between the two groups regarding the patients' average age and sex, probably because these factors did not influence COVID-19 infection. Other authors observed the same aspect in the literature (20). Regarding the average length of hospital stay, I noticed that it increased during the pandemic. We attributed this to the increasing severity of non-traumatic cases presented in the emergency services due to the decrease in patients' addressability to medical services during the COVID pandemic. Other authors report this fact in the literature (21).
Another interesting aspect of our statistics was the number of patients diagnosed with acute appendicitis and acute cholecystitis. The number of hospitalized and operated cases in our service during the pandemic decreased. There is a contradiction with other studies published in the literature (22). In A study published by Dick in 2020, authors concluded that the increase in the number of patients with acute appendicitis hospitalized is due to the SARS-COV-2 associating abdominal pain (23). This study has some limitations. The main limiting factor is the retrospective analysis of the study with no clear clinical manifestations in correlation with the actual pathology (progressive evolution of the patients). Also, another limiting factor is the fact that it is based only on the experience of a single medical center in Romania, whose specificity is different from other medical centers. Another limiting factor is that the pandemic group included patients admitted to our service during 2020, a year in which specific legal regulations were imposed in Romania that drastically limited patients' access to medical services. Adaptative protocols at the beginning imposed PCR testing for suspect patients before admission that drastically delayed surgery. Another factor is that surgery was performed in a different dedicated operation room that further added logistic delays from the diagnosis. We recommend a faster method by implementing rapid testing in patients with severe symptomatology, especially in acute abdomen cases. Operating rooms can be converted at a given time to reduce the logistic delays. Also, communication with the emergency department is needed to synchronize the surgical and intensive care teams to obtain a safe environment with rapid intervention. Combining these elements can reduce the time between diagnosis and surgical treatment (3).

\section{Conclusion}

In conclusion, the COVID-19 pandemic has played an essential role in treating surgical acute abdomen cases. Advanced pathological 
status and logistic delays reduced total admitted cases with prolonged hospitalization. In addition, the high solicitation rate of the emergency department also played a role. As the scale of this pandemic is unprecedented, adaptative protocols with minor changes do not provide adequate results. Implementation of emergency protocols that focus on the general status of the patient (clinical manifestations and history of the disease) with rapid testing or PCR testing at the emergency triage in the future can ensure proper treatment of these patients. Coordination with operating rooms adaptability can also reduce the delay imposed by logistic elements.

\section{Conflict of Interest}

The authors declare no conflicts of interest.

\section{Ethics Approval}

The institution's ethics committee approved the study.

\section{References}

1. Zhong P, Xu J, Yang D, Shen Y, Wang L, Feng Y. COVID-19-associated gastrointestinal and liver injury: clinical features and potential mechanisms. Signal Transduct Target Ther. 2020;5(1):256.

2. Hakkenbrak NAG, Loggers SAI, Lubbers E, de Geus J, van Wonderen SF, Berkeveld E, et al. Trauma care during the COVID-19 pandemic in the Netherlands: a level 1 trauma multicenter cohort study. Scand J Trauma Resusc Emerg Med. 2021;29(1):130.

3. Kühn F, Klein M, Laven H, Börner N, Weinberger T, Streitparth F, et al. Specific Management of Patients with Acute Abdomen during the COVID-19 Pandemic: A Surgical Perspective from Germany. Visc Med. 2020;36(5): 417-420.

4. Jacob S, Mwagiru D, Thakur I, Moghadam A, Oh T, Hsu J. Impact of societal restrictions and lockdown on trauma admissions during the COVID19 pandemic: a single-centre cross-sectional observational study. ANZ J Surg. 2020:90(11):2227-2231.

5. Rozenfeld M, Peleg K, Givon A, Bala M, Shaked G, Bahouth H, et al. COVID19 Changed the Injury Patterns of Hospitalized Patients. Prehosp Disaster Med. 2021;36(3):251-259. Epub 2021 Mar 1.

6. Dwi Nur Tyastono R, Bagus BI, Agrensa RS, Singgih NM. Postoperative pneumonia after abdominal surgery and the role on the unfavorable outcome: evaluation on emergency abdominal surgery patients with COVID-19. Clinical Gastroenterology, http://dx.doi.org/10.1136/gutjnl-2021-IDDF.112.

7. Rasslan R, dos Santos JP, Metidieri Menegozzo CA, Alvarez Pezzano AV, Simonsen Lunardeli H, dos Santos Miranda J, Massazo Utiyama E, Bastos Damous SH. Outcomes after emergency abdominal surgery in COVID 19 patients at a referral center in Brazil. Updates Surg. 2021;73(2):763-768.

8. Bresadola V, Biddau C, Puggioni A, Tel A, Robiony M, Hodgkinson J, et al. General surgery, and COVID-19: a review of practical recommendations in the first pandemic phase. Surg Today. 2020;50(10):1159-1167.

9. Kamer E, Çolak T. What to do when a patient infected with COVID-19 needs an operation: a pre-surgery, peri-surgery, and post-surgery guide. Turk J Colorectal Dis. 2020;30:1-8

10. Kah Ti L, Stella Ang L, Wai Foong T, Su Wei Ng B. What we do when a COVID-19 patient needs an operation: operating room preparation and guidance. Can J Anesth/J Can Anesth. 2020;67:756-8.

11. Coccolini F, Perrone G, Chiarugi M, Di Marzo F, Ansaloni L, Scandroglio I, et al. Surgery in COVID-19 patients: operational directives. World J Emerg Surg. 2020;15(1):25.

12. Ti LK, Ang LS, Foong TW, Ng BSW. What we do when a COVID-19 patient needs an operation: operating room preparation and guidance. Can J Anaesth. 2020;67(6):756-758.

13. Acemoglu O, Erol Cl, Kayali A, Acar M, Colapkulu N, Leblebici M, et al. Emergency Surgery During COVID-19 Pandemic; What Has Changed in Practice?, Br J Surg. 2020;107(12):e581-e582.

14. Ives J, Huxtable R. Surgical ethics during a pandemic: moving into the unknown? Br J Surg. 2020;107(9):1089-1090.

15. Herrod PJJ, Adiamah A, Boyd-Carson H, Daliya P, El-Sharkawy AM, Sarmah PB et al. Winter cancellations of elective surgical procedures in the UK: a questionnaire survey of patients on the economic and psychological impact. BMJ Open. 2019;9(9):e028753.

16. Rodriguez-Morales AJ, Cardona-Ospina JA, Gutiérrez-Ocampo E, Villamizar-Peña R, Holguin-Rivera Y, Escalera-Antezana JP et al. Clinical, laboratory and imaging features of COVID-19: a systematic review and meta-analysis. Travel Med Infect Dis. 2020;34:101623.

17. Søreide K, Hallet J, Matthews JB, Schnitzbauer AA, Line PD, Lai PBS, et al. Immediate and long-term impact of the COVID-19 pandemic on delivery of surgical services., Br J Surg. 2020;107(10):1250-1261.

18. Ai T, Yang Z, Hou H, Zhan C, Chen C, Lv W et al. Correlation of chest CT and RT-PCR testing in coronavirus disease 2019 (COVID-19) in China: a report of 1014 cases. Radiology. 2020;296(2):E32-E40.

19. Han H, Yang L, Liu R, Liu F, Wu KL, Li J et al. Prominent changes in blood coagulation of patients with SARS-CoV-2 infection. Clin Chem Lab Med. 2020;58(7):1116-1120.

20. Pagano MB, Hess JR, Tsang HC, Staley E, Gernsheimer T, Sen N et al. Prepare to adapt: blood supply and transfusion support during the first two weeks of the 2019 novel coronavirus (COVID-19) pandemic affecting Washington State. Transfusion. 2020;60(5):908-911.

21. Jin JM, Bai P, He W, Wu F, Liu XF, Han DM, et al. Gender differences in patients with COVID-19: focus on severity and mortality. Front Public Health. 2020;8:152.

22. Dick L, Green J, Brown J, Kennedy E, Cassidy R, Othman S, Berlansky M. Changes in Emergency General Surgery During Covid-19 in Scotland: A Prospective Cohort Study. World J Surg. 2020;44(11):3590-3594.

23. Saeed U, Sellevoll HB, Young VS, Sandbaek G, Glomsaker T, Mala T. Covid-19 may present acute abdominal pain. Br J Surg. 2020;107(7):e186-187. 